\title{
Thinking about Crime: Race and Lay Accounts of Lawbreaking Behavior
}

\section{Citation}

Thompson, Victor R., and Lawrence D. Bobo. 2011. Thinking about crime: race and lay accounts of lawbreaking behavior. The ANNALS of the American Academy of Political and Social Science 634(1): 16-38.

\section{Published Version}

doi:10.1177/0002716210387057

\section{Permanent link}

http://nrs.harvard.edu/urn-3:HUL.InstRepos:11223561

\section{Terms of Use}

This article was downloaded from Harvard University's DASH repository, and is made available under the terms and conditions applicable to Open Access Policy Articles, as set forth at http:// nrs.harvard.edu/urn-3:HUL.InstRepos:dash.current.terms-of-use\#OAP

\section{Share Your Story}

The Harvard community has made this article openly available.

Please share how this access benefits you. Submit a story.

Accessibility 


\section{Thinking About Crime:}

\section{Race and Lay Accounts of Law-Breaking Behavior*}

Victor R. Thompson, Stanford University

Lawrence D. Bobo, Harvard University

14 September 2009

*An earlier version of this paper was presented at the Annual American Association for Public Opinion Research conference in Hollywood, Florida, May 17, 2009. We wish to thank Alicia Simmons for her comments on an earlier draft of this paper. The authors are responsible for any remaining errors or shortcomings. Please direct correspondence to: Prof. Lawrence D. Bobo, Department of Sociology, Harvard University, William James Hall, Cambridge, MA. 02138. 


\begin{abstract}
Thinking about Crime:

Race and Lay Accounts of Law-Breaking Behavior
\end{abstract}

Lay or common sense accounts of the origins of criminal behavior may play both a key role in sustaining the apparently strong public appetite for harsh criminal justice policies as well as undergird large black-white differences in opinion in this domain. Using data from the nationally representative 2001 "Race, Crime, and Public Opinion Study" we develop an explanatory mode typology of accounts for involvement in criminal behavior. These accounts range from strongly individualistic to strongly social structural, with some respondents falling into a mixed mode category. We identify key differences in the demographic and sociopolitical bases of the attributional types and find significant race differences in attributional types. Attributions strongly affect how individuals wish to see public policy respond to the problem of crime and explain a small but significant fraction of the black-white difference in crime policy views. 


\section{INTRODUCTION}

Matters of law enforcement and criminal justice remain sites of deep racial tension in the U.S. Newsworthy flare-ups over police shootings, accusations of racial profiling, and a "War on Drugs" regarded by many as both excessive and unsuccessful highlight a pointedly race-inflected divide regarding the problem of crime in the U.S. and appropriate policy responses to it (Wacquant 2001; Kennedy 2003; Roberts 2003; Western 2006; Tonry and Melewski 2008). In this research we focus on one possible source of this racial polarization: namely, whether there are significant differences in how white and black Americans understand the very problem of crime itself.

High profile events and some key crime response policies (i.e., the crack versus powder cocaine sentencing differential) may elicit sharply polarized reactions from blacks and whites primarily because the groups have very different basic understandings of the sources of criminal behavior. For example, those who generally understand criminal behavior as rooted in personal dispositions and irresponsible individual choices may be inclined to endorse aggressive and punitive responses to crime in policing and in social policy. Alternatively, those who generally understand criminal behavior as having systematic social roots in conditions of poverty, unemployment, or other societal impediments may recoil against such punishment-centered styles of response to crime. If distinctive ways of thinking about the sources of criminal behavior vary systematically by race, then 
blacks and whites may, in sum, be worlds apart in the basic social meanings they attach to criminal behavior.

We seek to shed light on this possibility using data from the "Race, Crime, and Public Opinion" project (RCPO), which allows us to assess the extent, sources, and effects of black-white differences in attributions for criminal behavior (Bobo and Johnson 2001) ${ }^{1}$. The RCPO survey involves large national samples of white and black Americans and includes measures of beliefs about the causes of criminal behavior. The RCPO also contains measures of other factors relevant to judgments about crime such as an individual's prior victimization, fear of crime, general sociopolitical identities and ideology, as well as policy views on crime. In addition, we are able to append to these data key contextual information about actual levels of serious crime in the respondent's community.

\section{BACKGROUND}

The Attribution Process: Social psychologists have long maintained that the meaning social phenomenon have for us turns crucially on how we explain or account for observable social phenomenon (Heider 1958). That is, meaning is importantly bound up with the everyday process of attribution making, or more specifically, it involves how we construct causal accounts for the phenomenon we observe. Heider's (1958) groundbreaking work on internal or dispositional attributions and external or situational attributions is a useful specification of how

\footnotetext{
${ }^{1}$ Description and reports on the surveys (Bobo and Johnson 2004) and focus groups (Bobo 2004; Bobo and Thompson 2006) have appeared elsewhere (see also Johnson 2008; Bobo and Thompson 2009).
} 
causal attributions influence the assessment of individual responsibility. For example, following Heider's reasoning, individuals who believe the unemployed are jobless because they have a poor work ethic, an internal attribution, are more likely to see the jobless as personally responsible for their lack of employment. However, individuals who believe that unemployment is rooted in poor economic conditions, an external attribution, are much less likely to hold individuals responsible for their unemployment, instead focusing on broad structural conditions. In other words, the causal locus of the attribution has fundamental consequences for how people evaluate and perceive the actions of others.

Weiner's (1974) typology expanded on Heider's (1958) categories to include both a locus of causality (internal/external) dimension in addition to a stability dimension (stable/unstable). Accordingly, people may make attributions for behavior that involve an internal and stable attribute (i.e., "She did well on the test because she is highly intelligent"). Or they may make an attribution to an internal but unstable characteristic (i.e., "She did well on the test because she studied particularly hard this time"). Likewise, attributions may be made to stable but external factors ("She did well on the test because it's an easy exam") or to unstable external factors (i.e., "It was just luck that she did well on the exam" [Weiner 1974]). The combination of these two dimensions into one typology was widely accepted as a model for understanding lay attributions. And while there have since been many variations of this typology, the strength of the Weiner (1974) insight continues to serve as a useful framework through which to understand causal attributions for behavior. 
Much experimental social psychological research on attribution processes, however, focuses on judgments about the sources of individual task performance or direct interpersonal interaction. Sociologists and political scientists have extended these insights to attributions about larger matters of observable supra-individual processes and social conditions. Thus, for example, previous research sought to measure distinct patterns of popular belief about the causes of social inequality more generally (Kluegel and Smith 1986; Wilson 1996) and with regard to racial inequality in particular (Schuman 1971; Apostle et al 1983; Sniderman and Hagen 1985; Kluegel 1990; Hunt 2004; 2007).

Sociological attribution: Previous sociological research provides grounds to expect a strong tendency toward individualistic thinking when it comes to attributions about crime. Work on beliefs about general economic inequality has pointed to a dominant individualistic ethos or ideology in U.S. public opinion (Mann 1970; Huber and Form 1971; Kluegel and Smith 1986). Kluegel and Smith (1986) summarize this tendency via what they term a "logic of opportunity syllogism." The major premise holds that there are many opportunities for economic advancement in American society. Next, the logic goes, hard work and talent are rewarded in American society. Therefore, any resulting economic inequality is largely seen as the fair and legitimate result of differences in individual effort and ability. It seems reasonable to expect, therefore, that a similar strong general individualistic tilt may also exist when the focus shifts from economic inequality in general to the sources of involvement in crime in particular. 
Not everyone, to be sure, endorses an entirely individualistic account of social inequality. In particular, lower income individuals as compared to high income individuals, blacks as compared to whites (especially), and those with strong liberal political identities as compared to conservatives, are all more likely to recognize external, supra-individual or structural constraints on economic opportunity (Kluegel and Smith 1986; Bobo 1991).

The research on how Americans perceive and explain racial inequality has stressed the existence of distinct modes of explanation for race inequality (Apostle et al. 1983; Sniderman and Hagen 1985; Kluegel 1990; Sigelman and Welch 1991; and Hunt 2007). These modes reflect the fact that few people express, single unicausal accounts of racial inequality and that many individuals recognize the operation of both individual level factors as well as external or structural factors. As might be expected, however, these "modes of explanation" vary considerably by race (Hunt 2007; Kluegel and Smith 1986; Sniderman and Hagen 1985). African Americans are far more likely to attribute racial inequality to structural factors such as discrimination or inadequate educational opportunities as compared to whites who exhibit a clearer tendency to accept various dispositional or individualistic accounts (Kluegel 1990).

Furthermore, racial differences in basic "modes of explanation" help to explain black-white differences in support for race-targeted policies (Kluegel 1990). For example, whites who adopt individualist explanations for inequality are much less likely to support policies that seek government spending or aid to address racial 
inequality in the United States than whites who have a more structurally oriented explanation for inequality (Kluegel 1990). The sizeable gap in black and white explanations for inequality remained largely unabated throughout the 1970's and 1980's (Kluegel and Smith 1986) and as some recent work suggests became slightly less polarized in the 1990's and 2000's (Hunt 2007).

Still, there is a dearth of research on "modes of explanation" in the context of the public response to crime and the matter of crime-related policy. Much of the available research tends to focus on perceptions of the criminal justice system's response to particular types of behavior (Carroll and Payne 1976; Carroll 1978) rather than on how people understand the origins of criminal behavior itself. There has been to our knowledge little, if any, research on how individualist and structuralist accounts of behavior help to explain black and white differences in the evaluation of the criminal justice system and crime policy. In addition, the existing information on racial differences in causal accounts of criminogenic behavior remains largely descriptive in nature and is incomplete for recent years (see Erskine 1974) ${ }^{2}$. Given the polarization of attitudes between blacks and whites toward the criminal justice system in general (Hurwitz and Peffley 2005; Hagan, Shedd, and Payne 2005) and toward such issues as the War on Drugs in particular (Bobo and Thompson 2006), it is possible that racial differences in causal accounts of criminal behavior could help to explain differential support for punitive crime policies.

\footnotetext{
${ }^{2}$ Erskine (1974) provides a good summary of polling results on the public understanding of criminogenic behavior. However, there is a large gap in scholarship on polling trends post-1970 and the more recent scholarship tends to focus on the response to crime rather than the causes of crime (Shaw et al. 1998).
} 
$\underline{\text { Race and attributions: }}$ There are four important reasons to expect differences in causal explanations for crime among blacks and whites. First, despite enormous change and progress over the past several decades, African Americans remain socio-economically disadvantaged relative to whites and sharply segregated from whites in terms of residential location (Massey 2006). Such profound structural differences in social location are quite likely to influence thinking about a socially defined and constructed problem such as crime. Second, and more specifically, blacks and whites have historically encountered (Higginbotham 1996; Kennedy 1997) and certainly perceive in the present (Weitzer and Tuch 2006) very different experiences when it comes to their interactions with police and other institutions of the criminal justice system (Tonry 1995; Cole 1999; Mauer 1999; Western 2006). Given these sharply different statuses, histories and contemporary experiences we believe whites and blacks are likely to have polarized views of the causes of crime.

Thirdly, the perception by some that there is a racially biased system of social control (Quinney 1970; Chambliss and Seidman 1971; Hurwitz and Peffley 2005) that reproduces inequality, leading many to question the very legitimacy of the system (Hagan, Shedd, and Payne 2005; Bobo and Thompson 2006), may also act to polarize public opinion about the origins of crime that lead to these disparities in the first place. Lastly, real differences in exposure to crime among blacks and whites (Bobo and Thompson 2010) suggest a pervasive experiential gap in exposure to crime and criminals that may lead to very different beliefs about criminogenic behavior (Pettit and Western 2004). For example, Bobo and Thompson (2010) 
found that blacks were much more likely to have a friend or relative incarcerated than white respondents. This was true, regardless of income level or education. Indeed, even among the middle-class, those with a college education earning more than $\$ 60 \mathrm{~K}$ a year, nearly 1 in 3 blacks had a friend or relative incarcerated compared to only 1 in 20 whites. Exposure to the American criminal justice system is far more common in the black community than in the white community.

Ideology and attributions: Beyond race itself, value based and ideological differences between individuals might also be a determining factor for how people understand the causes of crime in addition to the types of crime policy they support (Tyler and Weber 1982; Tyler and Boeckmann 1997; Bobo and Johnson 2004; Gottschalk 2008). In particular, we know that political conservatism is highly correlated with support for such things as the death penalty, three-strike laws , and truth in sentencing laws (Soss, Langbein and Metelko 2003; Barkan and Cohen 2005; Unnever and Cullen 2007; Matsueda and Drakulich 2009). Therefore, it seems likely that a logic of personal responsibility is one of the factors that links value and ideological conservatism, on the one hand, to support for punitive policies on the other. The attribution process may be a key piece of this logic. Accordingly, those individuals of very traditional and conservative outlooks should be more likely than those of more liberal outlooks to make individualistic attributions about criminal behavior.

Crime salience and attributions: Actual exposure to serious crime may also shape attributions. For multiple reasons, individuals who live in high crime areas, 
who have been victimized, and who are highly fearful of crime may be motivated to see crime as more often a matter of individual responsibility than of social or structural causation. A more individualistic view of criminal behavior would be consistent with an agentic, and therefore, potentially more rationally controllable and manageable view of the crime problem. Such a view would also be a way of imposing a greater sense of right and wrong, or of moral order, on one's social surroundings and life circumstances. A personal or individual account of criminal behavior would also be a cognitively simple inference from the more general American cultural tendency toward individualism. That is, it is reasonable to expect those for whom crime is a highly salient personal matter to lean in the direction of more individualistic accounts as doing so should be more psychologically parsimonious and comforting at several levels.

In the end, we suspect all of these factors may determine support for crime policy and causal accounts of criminogenic behavior. We seek however to understand how causal accounts of criminogenic behavior help to explain the polarized views that blacks and whites have of the criminal justice system, especially their support for crime policies, independent of these other factors. That is, does mode of explanation explain the racial gap in support for crime policy even after these other factors are controlled? Are the opinions of blacks and whites largely the product of fundamental differences in opinion about the sources of crime? If so, how much of their support for particular crime policies can we explain by these differences? 


\section{ANALYSIS AND RESULTS}

A. Lay Accounts of Involvement in Crime:

In order to ascertain popular or lay accounts of criminal behavior, the Race, Crime and Public Opinion survey posed a series of four questions to respondents, in an agree/disagree format, specifying different potential root causes of criminal behavior. The four statements and respective response distributions are shown in Table 1. Of the four questions, the most widely endorsed lay account of crime involvement is that "people become criminals because they don't care about the rights of others or their responsibility to society"--a full $88.2 \%$ of whites and $73.8 \%$ of blacks endorse this explanation. The next most commonly accepted statement involves the structurally oriented belief that "poverty and low income in our society are responsible for much of crime", with $61.7 \%$ of whites and $67.4 \%$ of blacks endorsing this position. Finally, a smaller number of respondents believed that people turn to crime because they are lazy (Whites $=51.4 \%$; Blacks $=37.0 \%$ ) or that people turn to crime because our society does not guarantee that everyone has regular employment $($ Whites $=24.8 \%$; Blacks $=49.5 \%)$.

[Table 1 about here]

The distributions in Table 1 immediately suggest that most respondents affirm both some degree of personal or individualistic responsibility for criminal behavior as well as some situational or social structural accounts. Very similar 
tendencies toward an apparent multi-causal view of race-based inequality led Apostle and colleagues (1983), Sniderman and Hagen (1985), Kluegel (1990), and Hunt (2007) to identify distinctive modes of explanation of race inequality reflecting the intersection of the degree of acceptance of particular structural and individual accounts. We follow this analytical approach. Specifically, we employed a set of criteria for determining different "modes of explanation" for involvement with crime similar to that used by Kluegel (1990) and Hunt (2007). These scholars constructed modes of explanation for how respondents explained the Black-White socioeconomic gap using questions that tapped four possible outcomes, two of which were "person-centered/individualist" in nature (in-born ability and motivation), ${ }^{3}$ and two of which were structural in nature (discrimination and education). Our own set of questions measure similar dispositions toward crime involvement, and like Kluegel (1990) and Hunt (2007) we model our modes of explanation on the joint configuration of responses people used to explain involvement in crime.

Respondents often endorse more than one explanation for why some people commit crime. For example, $91.7 \%$ of those who agree that "laziness" explains why people commit crimes also agree that people turn to crime because they "don't care about the rights of others" (whites $=95.9 \%$; blacks $=86.0 \%$ ). And although there is

\footnotetext{
${ }^{3}$ Hunt's (2007) terminology differs from Kluegel (1990) in that Hunt uses "personcentered" to describe these traits because the "lack of ability" response to the GSS question denotes a deterministic behavior rather than one that reflects individual choice. Unlike Kluegel (1990) and Hunt (2007), our "individualist” responses ("lazy” and "don't care") are presumably choices an individual makes and not the result of biological determinism.
} 
not as much overlap in the structuralist items, $82.3 \%$ of respondents who agree that the primary reason people turn to crime is because "society does not guarantee that everyone has regular employment" also agree that "poverty and low income" are causes for crime involvement (whites $=85.3 \%$; blacks $80.8 \%$ ).

The opposite is not true. That is, while most of those who agreed "laziness" was the reason people turned to crime also agreed that criminals "don't care about the rights of others," only $49.6 \%$ of people who thought criminals "don't care about the rights of others" also thought people turned to crime because they are lazy. Similarly, only $48.0 \%$ of persons who endorsed the "poverty" attribute also endorsed the "no employment guarantee" attribute for why people commit crime, ${ }^{4}$ compared to $82.3 \%$ for the opposite relationship. Although focused on criminal behavior, these findings mirror previous research by Kluegel (1990) and Hunt (2007).

Not unexpectedly, there is some overlap between individualist and structuralist "modes of explanation." In general, people are rarely either entirely individualists or entirely structuralist in their causal explanations for crime involvement. Indeed, 35\% of the population agreed that "laziness" contributed to involvement in crime while also agreeing that "no employment guarantees" contributed to criminality, though much of this overlap occurred within the black population $-50.0 \%$ of blacks agreed with both of these attributes compared to only

\footnotetext{
4 The exact reason for this is beyond the scope of this paper. We should note however, that Kluegel (1990) and Hunt (2007) find a similar relationship in the General Social Survey data.
} 
$23.7 \%$ of whites. A similar pattern exists when comparing those who believe people turn to crime because they "don't care about the rights of others." Likewise, those who endorsed structuralist explanations for crime also agreed at times with individualist explanations. For example, $43.4 \%$ of those who believed "poverty" led people to criminal involvement also believed it was a product of people being "lazy" (whites $=49.5 \%$; blacks $=38.0 \%$ ). Given this overlap, we found it necessary to construct a mixed category for those who endorsed both structuralist and individualist views equally.

B. Modes of Explaining Crime:

Table 2 shows the joint configuration of responses we used to determine different "modes of explanation." We sorted respondents who were exclusively individualist or structuralist in their responses in to either an individualist or structuralist "mode of explanation." Individualists are people who endorsed either one or both individualist attributes and neither structuralist attribute, or they accepted both individualist attributes but also endorsed one of the structuralist attributes. ${ }^{5}$ The same pattern applies to structuralists. That is, structuralists

\footnotetext{
${ }^{5}$ We initially considered a more complex 9-category explanatory mode typology. After extensive analysis we concluded this complexity was not warranted. That is, there were no significant advantages gained by introducing finer distinctions between categories. Specifically, we treated respondents who chose only individualist attributes or only structural attributes as "strong individualists" and "strong structuralists" and those who chose both individualist attributes and one structuralist attribute or both structuralist attributes and one individualist attribute as "weak individualists” and "weak structuralists," respectively. However, in our analysis of possible antecedents of explanatory mode membership and of the effects of modes on policy views there were few differences between several of these more finely grained groupings. The differences that do exist between groups are among white respondents. Southern whites were more
} 
endorsed either one or both of the structuralist attributes and neither individualist attribute, or they accepted both structuralist attributes but also endorsed one of the individual attributes.

[Table 2 about here]

In addition to these two polar modes of explanation, we created a "mixed" mode of attribution category for those who straddled the individualist/structuralist divide. We treated respondents as "mixed" if they affirmed one of each structuralist/individualist attribute but denied the other. For example, a "mixed" respondent might endorse the belief that people become criminals because they "don't care about the rights of others" (an individualist attribute), but they also endorsed the idea that "society does not guarantee that everyone has regular employment" (a structuralist attribute). About 1 in 3 of all blacks and whites fell in to this category (see Figure 1).

Finally, for whatever reason, a small portion of our sample did not endorse any attribute $(\mathrm{N}=79)$. Whether or not this was because they literally had no views of why people turn to crime, or whether they simply did not like the specific options we offered is difficult to assess. There are enough such individuals, however, to warrant treating them as a separate category. Blacks were significantly more likely to belong to this group than whites. Fifty-one were African American (5.3\% of African Americans) and 28 were white (2.9\% of whites). Within the white

likely to be "weak individualists" and ideologically conservative whites were more likely to be "strong individualists," all else equal. Older whites were also less likely to be "strong structuralists." 
population, political "independents" and "liberals" were more likely to fall into this group. Among blacks, "liberals" and respondents with high incomes were more likely to fall into this category. For both blacks and whites, those who feared crime the least were the most likely to fall in this category.

Figure 1 presents the modes of explanation for criminal behavior by race. Several interesting patterns emerge. First, the majority of respondents believe that people are criminals because of some individual disposition toward criminality. To wit, if we combined the individualist and mixed mode respondents, nearly 8 in 10 whites (81.9\%), and 6 in 10 blacks (62.1\%) endorsed at least one individualist attribute. Secondly, when we compare the "modes of explanation" by race, clear racial distinctions emerge. This is most apparent when we compare individualists and structuralists to each other. For instance, more than half of all whites $(51.7 \%)$, are individualists compared to less than 1 in 3 blacks (28.8\%). Comparatively, $32.6 \%$ of blacks are structuralists while only $15.2 \%$ of whites are structuralists. In short, whites are more individualist in their explanations while blacks are more evenly distributed across groups.

[Figure 1 about here]

Indeed, as Table 3 indicates, nearly 2 out of 3 individualists are white in our sample (63.9\% of individualists are white), while the opposite is true for structuralists (64.5\% of structuralists are black). If individualists are in fact more punitive in their approach to crime policy, and if more of them are white, it may be that a large percentage of the racial gap in support for policy is explainable by the 
fact that individualists tend to be white. That is, modes of explanation may be powerful explanatory variables for why blacks and whites have very different levels of support for crime policies that go beyond values and ideology, salience of crime, and demographic characteristics such as age and years of education.

[Table 3 about here]

\section{B. Factors Affecting Attributions for Crime}

Table 4 shows means for each of the modes of explanation in addition to the variables we think are important for whether or not people adopt a particular mode of explanation. We include basic demographic characteristics (Race, Gender, Region, Age, Education, and Income), along with value-based and ideological factors (Democrat, Independent, Republican, Conservatism, and Church Attendance), ${ }^{6}$ and exposure to crime variables (Victim of Crime, Index Crime, Murder Rate, and Fear of Crime). ${ }^{7}$

[Table 4 about here]

\footnotetext{
${ }^{6}$ For party identification, we asked respondents to identify as either a Democrat, Republican, or Independent. Conservatism was measured on a 5 point scale from "very liberal" to "very conservative" with "moderate" as a midpoint. Church attendance was constructed by creating a 6 point scale based on how often a person attended church over the last year: never; once a year or less; a few times a year; once or twice a month; once a week; more than once a week.

7 "Victim of crime" is a dummy variable for respondents who said their house or apartment had been burglarized in the last year, or someone in their household had been a victim of a violent crime. Index crime rates and murder rates are taken from the FBI's Uniform Crime Reports from 2000. Fear of crime is a 5 point scale ranging from "low fear of crime" to "high fear of crime" based on the responses to two questions that asked how often respondents feared "someone breaking into your house to steal things" and how often they feared "being robbed by someone who has a gun or knife."
} 
The background, value and ideological, and crime salience factors reveal significant differences between blacks and whites that may shape differences in attributional patterns, though these differences do not point in one direction. For example, blacks are significantly more likely than whites to identify as Democrats and liberals than are whites both patterns implying that blacks might take a more structuralist view of crime causation. However, blacks report more frequent church attendance than whites, which might encourage a more individual responsibility focused outlook on crime. Likewise, crime is a far more salient experience for blacks than whites, as blacks are more likely to report criminal victimization, more likely to fear crime, and actually live in higher crime areas.

But what do these gaps in social experience and identities mean when it comes to how people explain the sources of criminogenic behavior? Does exposure to crime weigh heavily on crime attributions or do ideological differences and demographic characteristics condition crime attributions? We explore these questions by modeling the independent effects of these variables, in addition to race, on support for each mode of explanation separately.

Table 5 presents coefficients for logistic regression models predicting each mode of explanation category both pooled across race and separately for black and white respondents. Several patterns are worthy of emphasis. First, the results show that the overall effects of race are strong for structural and individual attributions. Blacks were about 3 times $\left(e^{1.10}\right)$ more likely than whites to be structuralists and about $.44\left(e^{-82}\right)$ times less likely to be individualists. Second, beyond race, 
ideological conservatives and Republicans were more likely to be individualists and less likely to be structuralists, all else equal, though party affiliation does not seem to matter as much for structuralists as it does for individualist and mixed responses. In addition, among structuralists, Southerners and older people were less likely to adopt a structuralist mode of explanation while those who had a greater fear of crime were much more likely to have a structuralist mode of explanation.

\section{[Table 5 about here]}

We next asked if whites and blacks were somehow distinct in their approaches to explaining crime. Among whites, we find that conservatism is a significant factor in predicting crime attributions for individualists and structuralists, while ideological matters appear to be less influential among black respondents. However, what does seem to matter for blacks and not so much for whites is fear of crime. Yet, the direction of the effect is not what we expected. Blacks who fear crime the most were also the ones least likely to be individualists and most likely to have a mixed mode of explanation for understanding criminal behavior. Interestingly, among black structuralists, the only variables that proved to be significant were whether or not the respondent lived in the South and whether or not they were older. That is, older, Southern blacks were less likely than younger, non-Southern blacks to make a structuralist argument about crime origins. In the end, there do appear to be significant differences between blacks and whites in terms of how they explain crime. Next, we explore how these differences help to explain the polarization around support for crime policies. 


\section{Support for Punitive Policies}

We believe that different modes of explanation may in part help to explain the varying levels of support among blacks and whites for punitive policies. We test this claim by exploring two points of exposure to the criminal justice system and people's support for policies that either limit or expand the punitiveness of the American criminal justice system. We first address a policy that seeks to widen the net and expand the reach of police and punishment through increased spending on law enforcement personnel and prisons. We then explore support for a policy that seeks to ensure that those who do become incarcerated remain so for as long as possible by making parole boards more strict.

As Table 6 shows, there are large differences between blacks and whites in their support for these policies. For example, over half of all whites view spending more money on police and more prisons as a viable strategy, whether in conjunction with education and job training programs (45.2\%) or in ways that only focus on police and prisons (10.2\%). A much smaller percentage of blacks endorsed these same views, believing instead that education and job training programs would be a better investment when it comes to solving the nation's crime problem. And although the majority of both whites and blacks think that parole boards should be more strict, there is still a sizeable difference between blacks and whites when it comes to granting parole to people in prison- $77.7 \%$ of whites compared to $65.3 \%$ of blacks think parole boards should be more strict.

[Table 6 about here] 
Certainly, one of the causes of this racial polarization is a real crisis of legitimacy and lack of trust of the criminal justice system among blacks (Bobo and Thompson 2006). However, a somewhat different explanation for this large gap in support for policy may in fact be that blacks and whites have fundamentally different causal explanations for crime. If people with dispositional attributions for behavior are more likely to "blame the individual" for their failures, then there is good reason to believe that these same people would also be more likely to support more punitive crime policies (Carrol 1978). After all, if crime is primarily a product of individual traits, the best way to stop crime may simply be to capture more criminals by placing more police on the streets, building more prisons, and keeping them there longer by denying them parole.

\section{Spending solutions to crime}

For the first set of questions addressing solutions to crime, we use multinomial logit models (see Table 7) and find significant evidence for the claim that modes of explanation do indeed influence support for crime policies, net of all other variables in our models. When we compared the likelihood of support for each solution to crime relative to the other solutions, we found that mode of explanation was important when comparing support for education and job training spending relative to spending policies that contained an element of support for more police and prisons. This was especially true for individualists, who were much more likely than structuralists to advocate spending for police and prisons over education and job training. While there was support among individualists for 
education and job training, it was more likely to be in conjunction with spending for police and prisons than exclusively for education and job training. People who have dispositional attributions about the causes of crime are committed to policies that improve law enforcement and expand our capacity to incarcerate, and are less concerned with attacking the social and economic conditions that lead to crime in the first place. The same is true for mixed respondents when comparing "both equally" to "education and job training," however there are no significant differences between mixed respondents and structuralists when comparing spending for more law enforcement and policies that address the social and economic causes of crime.

\section{[Table 7 about here]}

As expected, conservatism remains important even after controlling for mode of explanation and race. Political conservatives are about twice as likely $\left(e^{.75}\right)$ for each unit increase in conservatism than political liberals to support spending for police and prisons over education and job training programs. In addition, they are more likely to support spending for police and prisons over spending policies that include an element of education and job training, and they are more likely to support police and prison spending in conjunction with education and job training spending over spending on education and job training alone. To be clear, the more conservative people are, the more they view the solution to crime as one that requires the expansion of law enforcement by putting more police on the streets and building more prisons and not just addressing social and economic problems. 
Similarly, Republicans were more likely to support spending for law enforcement as a deterrent to crime than addressing social and economic problems.

Exposure to crime also matters, though it is less consistent across models and in fact contradicts our initial expectations about its effects. Namely, the negative effect of fear of crime when comparing support for police or support for education and job training versus both equally is in the opposite direction of what we expected. That is, we initially thought fear of crime would lead people to support more spending for law enforcement, but we find instead that it is correlated with more support for a mixed strategy of spending as a solution to crime. We can only speculate that people who have a greater fear of crime are also more likely to live in places where the exposure to crime is greater. ${ }^{8}$ Thus, because of the more personal relationship to crime, they may take a more holistic approach to solving crime by supporting spending on both law enforcement and prisons while at the same time supporting spending that addresses the social and economic conditions that lead to crime.

We next direct our attention to the possibility that mode of explanation acts as an intervening variable in explaining racially polarized attitudes about the criminal justice system. In each of the models that contain "education and job training" as a comparison group, race is a strong predictor of support for spending policy before mode of explanation is introduced to our models (see Model 1) and continues to be significant even after we introduce mode of explanation. However,

\footnotetext{
${ }^{8}$ Supporting this claim is the fact that fear of crime is positively correlated with crime rates and negatively correlated with income and education.
} 
the introduction of the mode of explanation variables does help to partially explain away some of the effects of race. In the end, there is only a 15.6 percent decrease in the overall effects of race when comparing support for spending on police and prisons to more spending on education and job training, and a 12.2 percent decrease in the likelihood of support for education and job training compared to both equally (converted to probabilities before calculating percentage decrease). There is no effect on race in our models that compare support for more spending on police and prisons to both equally. Mode of explanation is an important part of the story behind the racial gap in support for crime spending policies, but it is not the entire story.

We can draw roughly two conclusions from these models. First, mode of explanation does have an independent effect on support for spending policies, irrespective of other factors. Similarly, it acts to explain part of the gap between blacks and whites, though, and this is important, not the entire gap. Secondly, mode of explanation, along with race, is only significant when the comparison group is education and job training. That is, the key distinction appears to be between those who support spending policies that focus entirely on education and job training compared to those who support spending for more law enforcement and prison, even if it includes an element of education and job training spending.

\section{Support for more strict parole boards}

Unfortunately, these spending policies only address the entry side of the crime problem in America. In cases where crime prevention fails, the next question 
becomes what to do with convicted criminals once we have them, and if we do decide to incarcerate them, how long do we keep them locked up? As the number of prisoners in the nation's prisons continues to swell, the answer to this question becomes an important matter of public policy and human rights. In the next set of models we test the effects of mode of explanation on people's support for making parole boards more or less strict and find that mode of explanation does indeed predict support for these policies, independent of other variables.

First, the results from these models, shown in Table 8, reflect some of what we saw in the previous models when it comes to conservatism. Conservatives are more likely to support more strict parole boards than liberals. ${ }^{9}$ The effects of conservatism are equally strong before and after the mode of explanation variables are introduced, likely reflecting the strong current of "tough on crime" approaches within the dominant conservative political discourse. When it comes to conservatism, the effects are strong regardless of whether or not you are looking at solving the origins of crime or dealing with criminals once you have them.

[Table 8 about here]

Next, there were somewhat mixed results when it comes to exposure to crime and fear of crime. While crime rates have no impact on support for making parole boards more strict, fear of crime is an important part of the story. People who fear crime the most are also more likely to support stricter parole boards,

\footnotetext{
${ }^{9}$ We performed tests to determine whether or not there were differences between the "leave the same" and "less strict" categories and concluded that statistically speaking, there are no significant differences.
} 
independent of the crime rates and independent of mode of explanation. We also find that fear of crime is in the expected direction when it comes to attitudes about parole, indicating a more direct link between fear of crime and support for crime policies that promise to keep convicted criminals off the street longer. Ensuring that prisoners remain behind bars for as long as possible may act to alleviate some of the fear people have about crime.

Lastly, mode of explanation does have an impact on support for making parole boards more or less strict and seems to also have a small effect on race differences in policy outlooks. Individualists are 2.6 times more likely $\left(\mathrm{e}^{95}\right)$ to support stricter parole boards than structuralists, as are those in the mixed mode category, who are about 1.7 times more likely ( $\mathrm{e}^{.53}$ ) than structuralists. Besides race, mode of explanation is one of the most important predictors of support for stricter parole boards. However, race remains a strong predictor of support for parole boards being more strict regardless of what we introduce to the model, and the decrease in the likelihood of supporting more strict parole boards is only about $12.2 \%$ (converted to probabilities before calculating percentage decrease). Once again, we find mode of explanation to be a significant factor in explaining support for more punitive crime policies, yet it stops short of fully explaining the gap between blacks and whites, only marginally acting as an intervening variable.

A visual representation of these models may sum things up best. Figures $2 \mathrm{a}$ and $2 \mathrm{~b}$ show the main effects from both models after controlling for race and mode of explanation. First, individualists and structuralists, regardless of race, are not 
likely to support spending money only on police and prisons. All else equal, there tends to be more support for policies that include education and job training. Whites however, are somewhat split, with more individualist whites leaning toward support for policies that include some form of spending for police and prisons and white structuralists being slightly more supportive of policies that include spending for education and job training. Blacks on the other hand tend to lean toward policies that include spending for education and job training programs, reflecting a more liberal stance on how America should deal with crime. This is true for both types of policies in Figures 2a and 2b.

[Figures $2 \mathrm{a}$ and $2 \mathrm{~b}$ about here]

Perhaps the most striking finding in terms of whether or not whites and blacks are truly worlds apart when it comes to understanding the problem of crime is the fact that even the most externally oriented group of whites, structuralists, are hardly any different than the most dispositionally oriented group of blacks. Put differently, black individualists are substantively no different from white structuralists. Blacks and whites, despite the significant differences between structuralists and individualists within each racial group remain very polarized even when we take into account mode of explanation.

\section{DISCUSSION AND CONCLUSIONS}

Racial polarization on matters of law enforcement and criminal justice remains a problem. We sought to determine whether one factor underlying this polarization involved sharply different ways of explaining criminal behavior itself among black 
and white Americans. Our results point to real differences in the extent to which whites and blacks understand crime as having roots in individuals choices, dispositions and failings on the one hand, as opposed to situational or structural constraints and limitations, on the other. To be sure, we find that African Americans are substantially more likely than whites to adopt structuralist accounts for criminal behavior and that just the opposite pattern exists with regard to endorsing individualist accounts for crime. Yet, blacks and whites are about equally likely to adopt "mixed" accounts for crime, straddling the line between structural and individual views of criminal behavior. In sum, there are real differences in core attributional tendencies between blacks and whites. These differences, however, do not constitute a sort of gaping polarization in thinking about crime.

Beyond race, we find that values and ideology help to shape crime attributions. In particular, political ideology plays a clear role among whites, though it is less consistently influential among blacks. Among black respondents exposure to and particularly fear of crime do more to shape attributional mode.

Crime explanatory modes matter considerably for crime policy outlooks. As expected, structuralists are more likely than individualists or those offering mixed accounts, to stress a non-punitive response to crime. They are more supportive of trying to prevent crime with an emphasis on educational opportunities and jobs rather than on more police and prisons. They are also more likely to encourage less stringent practices by parole boards. Blacks and whites are significantly different on these policy matters in the expected directions. Race-linked differences in 
attributional patterns account for a part of the race-gap in policy views between blacks and whites. However, most of the gap remains even after we have taken into account black-white differences in crime explanatory modes.

The latter pattern suggests that other factors beyond the attributional process account for the black-white polarization in the domain of criminal justice. Some of these other factors may include differential personal, family, and community-based experiences with agents and institutions of the criminal justice system. It may also reflect a sort of group cultural identity and outlook. On the former, it seems that direct personal negative experiences with agents of the criminal justice system, or knowledge of bad experiences reported by family members and close friends is sufficiently common in the black community that these experiences create a pervasive cynicism about law enforcement and an expectation of race bias (Wilson and Dunham 2001). On the latter, these ideas are also sufficiently widely shared and longstanding that they may rise to the level of an aspect of group culture and identity, especially among the most politically engaged segments of the black population. To wit, the lion share of the foundation of polarized policy views and of enormous differences in expectancies for fair treatment may have more to do with direct experience and group culture than with fundamentally different understandings of the nature of crime. 


\section{Bibliography}

Apostle, Richard A., Charles V. Glock, Thomas Piazza, and Marijean Suelzle. The Anatomy of Racial Attitudes. Berkeley: University of California Press, 1983.

Barkan, Steven E. and Steven F. Cohen. "Why Whites Favor Spending More Money to Fight Crime: The Role of Racial Prejudice." Social Problems 52, (2005): 300-314.

Bobo, Lawrence D. "Social Responsibility, Individualism, and Redistributive Policies." Sociological Forum 6 (1991): 71-92.

Bobo, Lawrence D., and Devon Johnson. "Race, Crime, and Public Opinion Survey." 2001. Department of Sociology, Harvard University.

—. "A Taste for Punishment: Black and White Americans' Views on the Death Penalty and the War on Drugs." Du Bois Review 1, no. 1 (2004): 151-80.

Bobo, Lawrence D., and Victor R. Thompson. "Unfair by Design: The War on Drugs, Race, and the Legitimacy of the Criminal Justice System." Social Research: An International Quarterly of Social Sciences 73, no. 2 (2006): 445-72.

_. "Racialized Mass Incarceration: African Americans and the Criminal Justice System." In Doing Race: 21 Essays for the 21st Century, edited by Hazel Markus and Paula M. Moya. New York: Norton, 2010.

Carroll, John S. "Causal Theories of Crime and Their Effect Upon Expert Parole Decisions." Law and Human Behavior 2, no. 4 (1978): 377-88. 
Carroll, John S., and John W. Payne. "The Psychology of the Parole Decision Process: A Joint Application of Attribution Theory and Information Processing Psychology." In Cognition and Social Behavior, edited by John S. Carroll and John W. Payne, 13-32. Hillsdale, NJ: Erlbaum, 1976.

Chambliss, William J., and Robert B. Seidman. Law, Order, and Power. Reading, MA: Addison-Wesley Publishing Company, 1971.

Cole, David. No Equal Justice: Race and Class in the American Criminal Justice System. New York, NY: The New Press, 1999.

Erskine, Hazel. "The Polls: Fear of Violence and Crime." The Public Opinion Quarterly 38, no. 1 (1974): 131-45.

Gottschalk, Marie. "Hiding in Plain Sight: American Politics and the Carceral State." Annual Review of Political Science, 11 (2008): 235-260.

Hagan, John, Carla Shedd, and Monique R. Payne. "Race, Ethnicity, and Youth Perceptions of Criminal Injustice." American Sociological Review 70 (2005): 381407.

Heider, Fritz. The Psychology of Interpersonal Relations. New York: Wiley, 1958.

Higginbotham, A. Leon. Shades of Freedom: Racial Politics and Presumptions of the American Legal Process. New York, NY: Oxford University Press, 1996.

Huber, Joan, and William H. Form. Income and Ideology. New York, NY: Free Press, 
1973.

Hunt, Matthew O. "Race/Ethnicity and Beliefs About Wealth and Poverty." Social Science Quarterly 85, no. 3 (2004): 827-53.

_. "African American, Hispanic, and White Beliefs About Black/White Inequality, 1977-2004." American Sociological Review 72 (2007): 390-415.

Hurwitz, Jon and Mark Peffley. "Explaining the Great Racial Divide: Perceptions of Fairness in the U.S. Criminal Justice System." Journal of Politics 67 (2005): 762783.

Johnson, Devon. "Crime Salience, Perceived Racial Bias, and Blacks' Punitive Attitudes." Journal of Ethnicity in Criminal Justice 4, no.4 (2006): 1-18.

Kennedy, Joseph E. "Drug Wars in Black and White." Law and Contemporary Problems 66 (2003): 153-182.

Kennedy, Randall. Race, Crime, and the Law, New York: Vintage, 1997.

Kluegel, James R. "Trends in Whites' Explanations of the Black-White Gap in Socioeconomic Status, 1977-1989." American Sociological Review 55, no. 4 (1990): 512-25.

Kluegel, James R., and Eliot R. Smith. Beliefs About Inequality: Americans' Views of What Is and What Ought to Be. New York: Aldine de Gruyter, 1986.

Mann, Michael. "The Social Cohesion of Liberal Democracy." American Sociological Review 35 (1970): 423-39. 
Matsueda, Ross L, and Kevin Drakulich. "Perceptions of Criminal Injustice, Symbolic Racism, and Racial Politics." The Annals of the American Academy of Political and Social Science 623, no. 1 (2009): 163-178.

Mauer, Marc. Race to Incarcerate. New York: New Press, 1999.

Pettit, Becky, and Bruce Western. "Mass Imprisonment and the Life Course: Race and Class Inequality in U.S. Incarceration." American Sociological Review 69, no. 2 (2004): 151-69.

Quinney, Richard. The Social Reality of Crime. Boston: Little, 1970.

Roberts, Dorothy E. "The Social and Moral Cost of Mass Incarceration in African American Communities." Stanford Law Review 56, (2003): 1271-1305.

Schuman, Howard. "Free Will and Determinism in Public Beliefs About Race." In Majority and Minority: The Dynamics of Racial and Ethnic Relations, edited by Norman R. Yetman and C. Hoy Steele, 382-90. Boston: Allyn and Bacon, 1975.

Shaw, Greg M., Robert Y. Shapiro, Shmuel Lock, and Lawrence R. Jacobs. "The Polls-Trends." Public Opinion Quarterly 62, no. 3 (1998): 405.

Sigelman, Lee, and Susan Welch. Black Americans' Views of Racial Inequality: The Dream Deferred: Cambridge University Press, 1991.

Sniderman, Paul M., and Michael Gray Hagen. Race and Inequality: A Study in American Values, Chatham House Series on Change in American Politics. Chatham, NJ: Chatham House, 1985.

Soss, Joe, Laura Langbein, and Alan R. Metelko. "Why Do White Americans Support 
the Death Penalty." Journal of Politics 65 (2003): 397-421.

Tonry, Michael H. Malign Neglect--Race, Crime, and Punishment in America. New York, NY: Oxford University Press, 1995.

Tonry, Michael and Matthew Melewski. "The Malign Effects of Drug and Crime Control Policies on Black Americans." Crime and Justice: A Review of Research 37 (2008): 1-44.

Tyler, Tom R, and Renee Weber. "Support for the Death Penalty: Instrumental Response to Crime, or Symbolic Attitude." Law \& Society Review 17 (1982): 2146.

Tyler, Tom R, and Renee J Boeckmann. "Three Strikes and You Are out, but Why?_The Psychology of Public Support for Punishing Rule Breakers." Law \& Society Review 31, no. 2 (1997): 237-65.

Unnever, James D. and Francis T. Cullen. "Reassessing the Racial Divide in Support for Capital Punishment: The Continuing Significance of Race." Journal of Research in Crime and Delinquency 44, no 1., (2007): 124-158.

Wacquant, Loic. "Deadly Symbiosis: When Ghetto and Prison Meet and Mesh." Punishment and Society 3 (2001): 95-134.

Weiner, Bernard. Achievement Motivation and Attribution Theory. Morristown, N.J.,: General Learning Press, 1974.

Weitzer, Ronald J, and Stephen A Tuch. Race and Policing in America: Conflict and Reform: Cambridge University Press, 2006.

Western, Bruce. Punishment and Inequality in America. New York: Russell Sage, 2006. 
Wilson, George. "Toward a Revised Framework for Examining Beliefs about the Casues of Poverty." Sociological Quarterly 37, no 3, (1996): 413-428.

Wilson, George and Roger Dunham. "Race, Class, and Attitudes Toward Crime Control." Criminal Justice Behavior 28, no.3, (2001): 259-278. 
Table 1. Reasons why some people turn to crime.

\begin{tabular}{|c|c|c|}
\hline I ndividual Attributions & White & Black \\
\hline \multicolumn{3}{|c|}{$\begin{array}{l}\text { People turn to crime because they are lazy. } \\
\text { Strongly/Mostly agree }\end{array}$} \\
\hline Strongly/Mostly disagree & $48.6 \%$ & $63.0 \%$ \\
\hline $\mathrm{N}$ & 965 & 994 \\
\hline \multicolumn{3}{|c|}{$\begin{array}{l}\text { People become criminals because they don't care about the rights of } \\
\text { others or their responsibility to society. }\end{array}$} \\
\hline Strongly/Mostly disagree & $11.8 \%$ & $26.2 \%$ \\
\hline $\mathrm{N}$ & 969 & 997 \\
\hline \multicolumn{3}{|l|}{ Structural Attributions } \\
\hline \multicolumn{3}{|c|}{$\begin{array}{l}\text { People turn to crime because our society does not guarantee that } \\
\text { everyone has regular employment. }\end{array}$} \\
\hline Strongly/Mostly disagree & $75.2 \%$ & $50.5 \%$ \\
\hline $\mathrm{N}$ & 966 & 994 \\
\hline \multicolumn{3}{|c|}{$\begin{array}{l}\text { Poverty and low income in our society are responsble for much of } \\
\text { crime. }\end{array}$} \\
\hline Strongly/Mostly disagree & $38.3 \%$ & $32.6 \%$ \\
\hline $\mathrm{N}$ & 963 & 999 \\
\hline
\end{tabular}

Source: Race, Crime ad Public Opinion Survey, 2001 
Table 2. Response Patterns for "Mode of Explanation" for I nvolvement with Crime

\begin{tabular}{|c|c|c|c|c|c|c|}
\hline \multirow[b]{3}{*}{ Mode of Explanation } & \multicolumn{6}{|c|}{ Response Patterns } \\
\hline & \multicolumn{3}{|c|}{ Individual Attributions } & \multicolumn{3}{|c|}{ Structural Attributions } \\
\hline & Lazy & & Not Responsible & No Jobs & & Poverty \\
\hline Individualist & $\begin{array}{l}\text { Yes } \\
\text { Yes }\end{array}$ & (or) & $\begin{array}{l}\text { Yes } \\
\text { Yes }\end{array}$ & $\begin{array}{l}\text { No } \\
\text { Yes }\end{array}$ & (or) & $\begin{array}{l}\text { No } \\
\text { Yes }\end{array}$ \\
\hline Mixed & Yes & (or) & Yes & Yes & (or) & Yes \\
\hline Structuralist & $\begin{array}{l}\text { No } \\
\text { Yes }\end{array}$ & (or) & $\begin{array}{l}\text { No } \\
\text { Yes }\end{array}$ & $\begin{array}{l}\text { Yes } \\
\text { Yes }\end{array}$ & (or) & $\begin{array}{l}\text { Yes } \\
\text { Yes }\end{array}$ \\
\hline None & No & & No & No & & No \\
\hline
\end{tabular}

Source: Race, Crime and Public Opinion Survey, 2001 
Figure 1. Mode of Explanation by Race

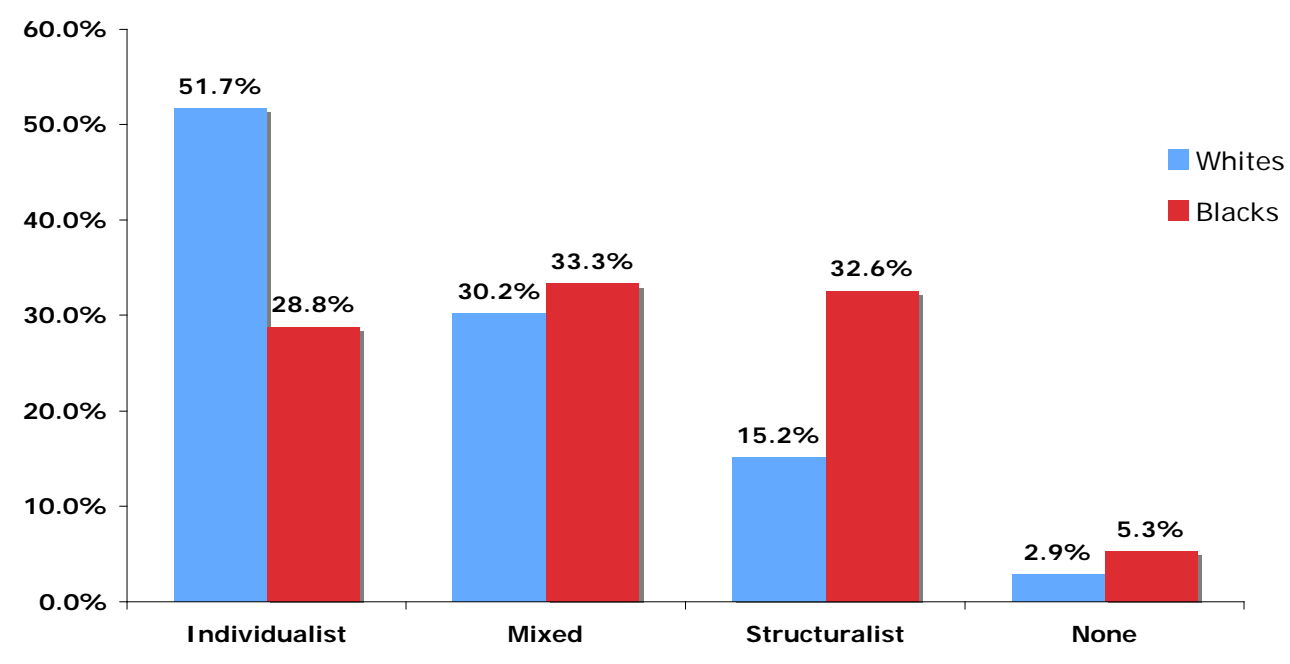

Source: Race, Crime and Public Opinion Survey, 2001 
Table 3. Mode of Explanation by Race

\begin{tabular}{lrrrr} 
& Whites & Blacks & Total & Percent White \\
\cline { 2 - 5 } I ndividualist & 494 & 279 & 773 & $\mathbf{6 3 . 9 \%}$ \\
Mixed & 288 & 323 & 612 & $\mathbf{4 7 . 2 \%}$ \\
Structuralist & 145 & 316 & 461 & $\mathbf{3 1 . 5 \%}$ \\
None & 28 & 51 & 79 & $\mathbf{3 4 . 9} \%$ \\
\cline { 2 - 5 } Total N & 955 & 970 & 1,925 & \\
\hline Source: Race, Crime and Public Opinion Survey, 2001 &
\end{tabular}


Table 4. Means and Standard Deviations by Race

\begin{tabular}{|c|c|c|c|}
\hline & Total & White & Black \\
\hline \multicolumn{4}{|l|}{ Mode of Explanation } \\
\hline Individualist & $\begin{array}{l}0.44 \text { ** } \\
(0.50)\end{array}$ & $\begin{array}{c}0.55 \\
(0.50)\end{array}$ & $\begin{array}{c}0.31 \\
(0.46)\end{array}$ \\
\hline Mixed & $\begin{array}{l}0.30 * * \\
(0.46)\end{array}$ & $\begin{array}{c}0.28 \\
(0.45)\end{array}$ & $\begin{array}{c}0.33 \\
(0.47)\end{array}$ \\
\hline Structuralist & $\begin{array}{l}0.21 \\
(0.41)\end{array}$ & $\begin{array}{c}0.13 \\
(0.34)\end{array}$ & $\begin{array}{c}0.30 \\
(0.46)\end{array}$ \\
\hline None & $\begin{array}{l}0.04 * * \\
(0.21)\end{array}$ & $\begin{array}{c}0.04 \\
(0.19)\end{array}$ & $\begin{array}{c}0.06 \\
(0.23)\end{array}$ \\
\hline \multicolumn{4}{|l|}{ Demographics } \\
\hline Female & $\begin{array}{l}0.56 * * \\
(0.50)\end{array}$ & $\begin{array}{c}0.54 \\
(0.50)\end{array}$ & $\begin{array}{c}0.57 \\
(0.50)\end{array}$ \\
\hline Southern & $\begin{array}{l}0.45 \quad * * \\
(0.50)\end{array}$ & $\begin{array}{c}0.35 \\
(0.48)\end{array}$ & $\begin{array}{c}0.57 \\
(0.49)\end{array}$ \\
\hline Age (in years) & $\begin{array}{l}45.19 * * \\
(16.17)\end{array}$ & $\begin{array}{c}47.47 \\
(16.45)\end{array}$ & $\begin{array}{c}42.45 \\
(15.38)\end{array}$ \\
\hline Education (in years) & $\begin{array}{l}13.33 * * \\
(2.49)\end{array}$ & $\begin{array}{l}13.63 \\
(2.50)\end{array}$ & $\begin{array}{l}12.96 \\
(2.43)\end{array}$ \\
\hline Income & $\begin{array}{l}\$ 49,366 \\
(\$ 32,943)\end{array} * *$ & $\begin{array}{c}\$ 52,763 \\
(\$ 32,426)\end{array}$ & $\begin{array}{c}\$ 45,287 \\
(\$ 33,119)\end{array}$ \\
\hline \multicolumn{4}{|l|}{ Value and Ideology } \\
\hline Democrat & $\begin{array}{l}0.50 * * \\
(0.50)\end{array}$ & $\begin{array}{c}0.32 \\
(0.47)\end{array}$ & $\begin{array}{c}0.73 \\
(0.45)\end{array}$ \\
\hline Independent & $\begin{array}{l}0.31 \\
(0.46)\end{array}$ & $\begin{array}{c}0.36 \\
(0.48)\end{array}$ & $\begin{array}{c}0.25 \\
(0.43)\end{array}$ \\
\hline Republican & $\begin{array}{l}0.19 * * \\
(0.39)\end{array}$ & $\begin{array}{c}0.32 \\
(0.47)\end{array}$ & $\begin{array}{c}0.02 \\
(0.15)\end{array}$ \\
\hline Conservatism $^{1}$ & $\begin{array}{l}2.99 * * \\
(0.83)\end{array}$ & $\begin{array}{c}3.13 \\
(0.85)\end{array}$ & $\begin{array}{c}2.83 \\
(0.77)\end{array}$ \\
\hline Church Attendance ${ }^{2}$ & $\begin{array}{l}3.73 * * \\
(1.56)\end{array}$ & $\begin{array}{c}3.46 \\
(1.60)\end{array}$ & $\begin{array}{c}4.06 \\
(1.45)\end{array}$ \\
\hline \multicolumn{4}{|l|}{ Salience of Crime } \\
\hline Victim of Crime & $\begin{array}{l}0.06 * * \\
(0.23)\end{array}$ & $\begin{array}{c}0.05 \\
(0.22)\end{array}$ & $\begin{array}{c}0.07 \\
(0.25)\end{array}$ \\
\hline Index Crime (per 100,000 ) & $\begin{array}{c}4,788.40 \\
(2,084)\end{array} * *$ & $\begin{array}{r}4,145.72 \\
(1,890)\end{array}$ & $\begin{array}{l}5,560.27 \\
(2,046)\end{array}$ \\
\hline Murder Rate (per 100,000 ) & $\begin{array}{c}9.11 \\
(10.67)\end{array}$ & $\begin{array}{c}5.67 \\
(7.39)\end{array}$ & $\begin{array}{c}13.23 \\
(12.42)\end{array}$ \\
\hline Fear of Crime ${ }^{3}$ & $\begin{array}{l}2.02 \\
(0.73)\end{array}$ & $\begin{array}{c}1.92 \\
(0.65)\end{array}$ & $\begin{array}{c}2.13 \\
(0.80)\end{array}$ \\
\hline
\end{tabular}

Source: Race, Crime and Public Opinion Survey, 2001

$* *$ Significant differences between white and black respondents $(p<0.05$, twotailed tests).

${ }^{1}$ Range $=1-5 ; 1=$ "Very liberal"; $5=$ "Very conservative"

${ }^{2}$ Range $=1-6 ; 1=$ "Never"; $6=$ "More than once a week"

${ }^{3}$ Range $=1-5$; $1=$ "Low Fear of Crime"; $5=$ "High Fear of Crime" 


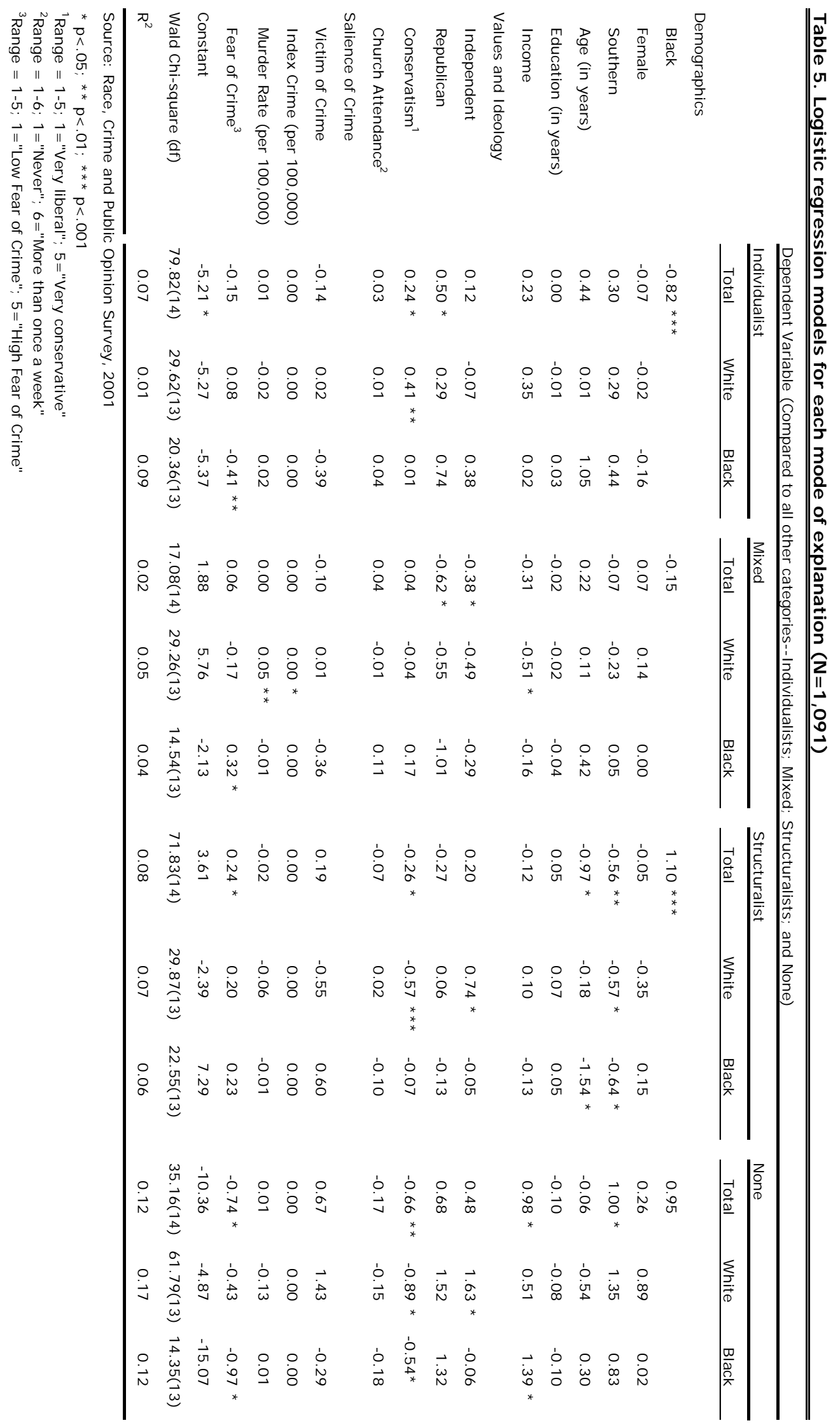


Table 6. Addressing Crime Problems in the U.S. by Race

\begin{tabular}{|c|c|c|c|}
\hline $\begin{array}{l}\text { Question } 1 \\
\text { To lower the crime rate in the U.S. some people think more money should be } \\
\text { spent on attacking the social and economic problems that lead to crime by } \\
\text { improving education and job training programs. Other people think more } \\
\text { money should be spent on improving law enforcement and deterring crime by } \\
\text { hiring more police and building more prisons. Which comes closer to your }\end{array}$ & Whites & Blacks & $\begin{array}{l}\text { White to } \\
\text { Black Ratio }\end{array}$ \\
\hline More money for education and job training & $35.2 \%$ & $57.7 \%$ & 0.6 \\
\hline Both equally & $45.2 \%$ & $35.1 \%$ & 1.3 \\
\hline More money for police and prisons & $10.2 \%$ & $1.3 \%$ & 8.0 \\
\hline Neither & $9.4 \%$ & $5.9 \%$ & 1.6 \\
\hline Total $\mathrm{N}$ & 781 & 721 & \\
\hline \multicolumn{4}{|l|}{$\begin{array}{l}\text { Question } 2 \\
\text { When it comes to granting parole to people in prison, should parole boards }\end{array}$} \\
\hline More strict & $77.7 \%$ & $65.3 \%$ & 1.2 \\
\hline Same as they are now/Less strict & $22.3 \%$ & $43.7 \%$ & 0.5 \\
\hline Total N & 775 & 713 & \\
\hline
\end{tabular}

Source: Race, Crime ad Public Opinion Survey, 2001 


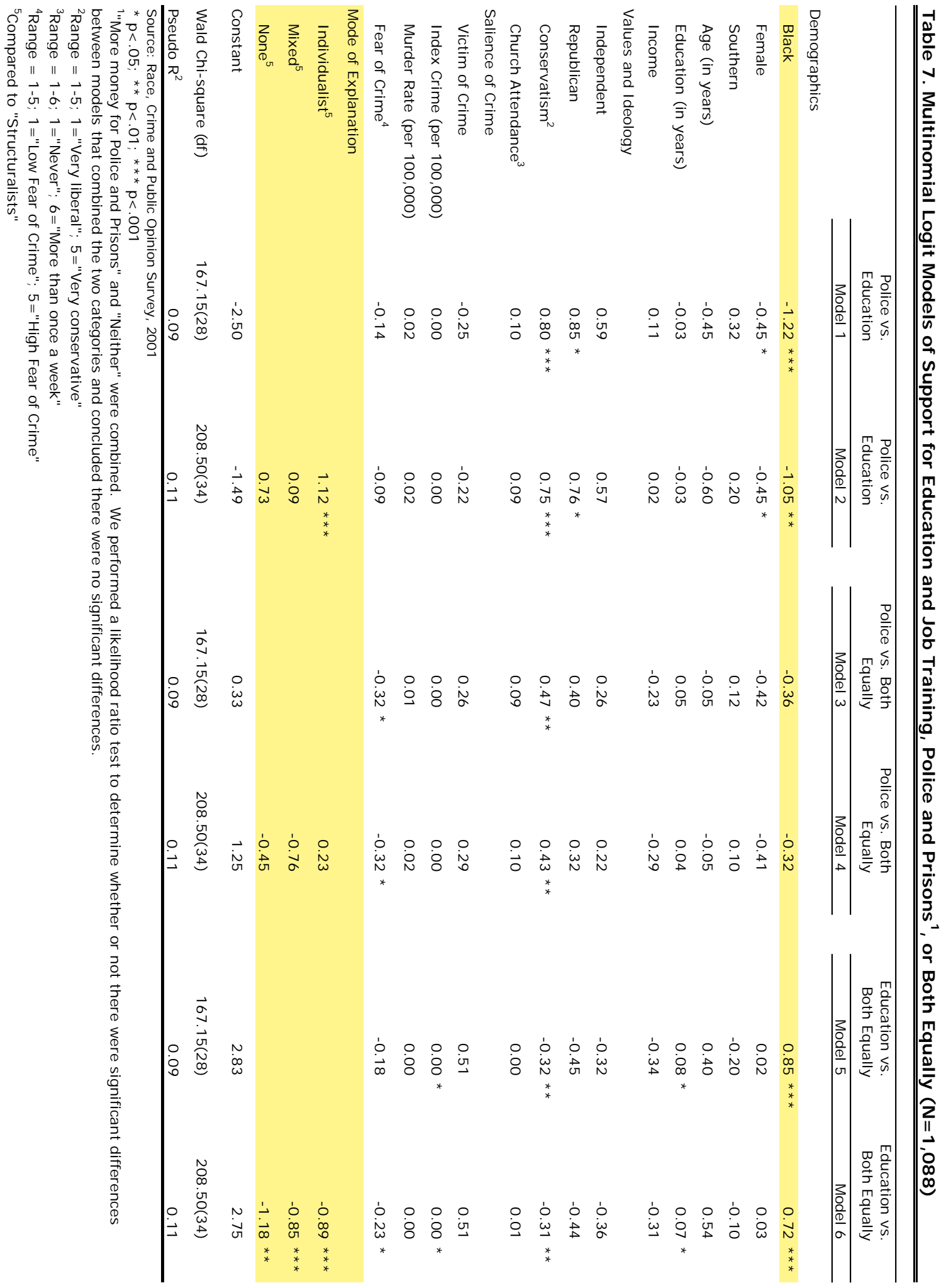


Table 8. Logistic Regression of Support for Making Parole Boards "More Strict" versus "Less Strict/ leaving them the same." 1

\begin{tabular}{|c|c|c|}
\hline & Model 1 & Model 2 \\
\hline \multicolumn{3}{|l|}{ Demographics } \\
\hline Black & $-1.01 * * *$ & $-0.89 * * *$ \\
\hline Female & $0.37 *$ & $0.39 *$ \\
\hline Southern & 0.18 & 0.09 \\
\hline Age (in years) & -0.66 & $-0.81 *$ \\
\hline Education (in years) & $-0.10 * *$ & $-0.10 * *$ \\
\hline Income & -0.06 & -0.10 \\
\hline \multicolumn{3}{|l|}{ Values and I deology } \\
\hline I ndependent & $-0.46 *$ & $-0.48 *$ \\
\hline Republican & -0.05 & -0.14 \\
\hline Conservatism $^{2}$ & $0.31 * *$ & $0.28 * *$ \\
\hline Church Attendance ${ }^{3}$ & 0.08 & 0.07 \\
\hline \multicolumn{3}{|l|}{ Salience of Crime } \\
\hline Victim of Crime & -0.14 & -0.10 \\
\hline Index Crime (per 100,000 ) & 0.00 & 0.00 \\
\hline Murder Rate (per 100,000 ) & 0.00 & -0.01 \\
\hline Fear of Crime ${ }^{4}$ & $0.35 * *$ & $0.42 * * *$ \\
\hline \multicolumn{3}{|l|}{ Mode of Explanation } \\
\hline Individualist ${ }^{5}$ & & $0.95 * * *$ \\
\hline Mixed $^{5}$ & & $0.53 *$ \\
\hline None $^{5}$ & & 0.81 \\
\hline Constant & 4.41 & 4.99 \\
\hline $\mathrm{N}$ & 1,077 & 1,077 \\
\hline Wald Chi-square( df) & $70.21(14)$ & $82.69(17)$ \\
\hline Pseudo $\mathrm{R}^{2}$ & 0.07 & 0.09 \\
\hline
\end{tabular}

Source: Race, Crime and Public Opinion Survey, 2001

${ }^{1}$ "Same" and "Less Strict" were combined. We performed a likelihood ratio test to determine whether or not there were significant differences between models that combined the two categories and concluded there were no significant differences.

${ }^{2}$ Range $=1-5 ; 1=$ "Very liberal"; $5=$ "Very conservative"

${ }^{3}$ Range $=1-6 ; 1=$ "Never"; $6=$ "More than once a week"

${ }^{4}$ Range $=1-5 ; 1=$ "Low Fear of Crime"; $5=$ "High Fear of Crime"

${ }^{5}$ Compared to "Structuralists" 
Figure 2a. Predicted Probability of Support for Crime Solutions for Individualists and Structuralists by Race

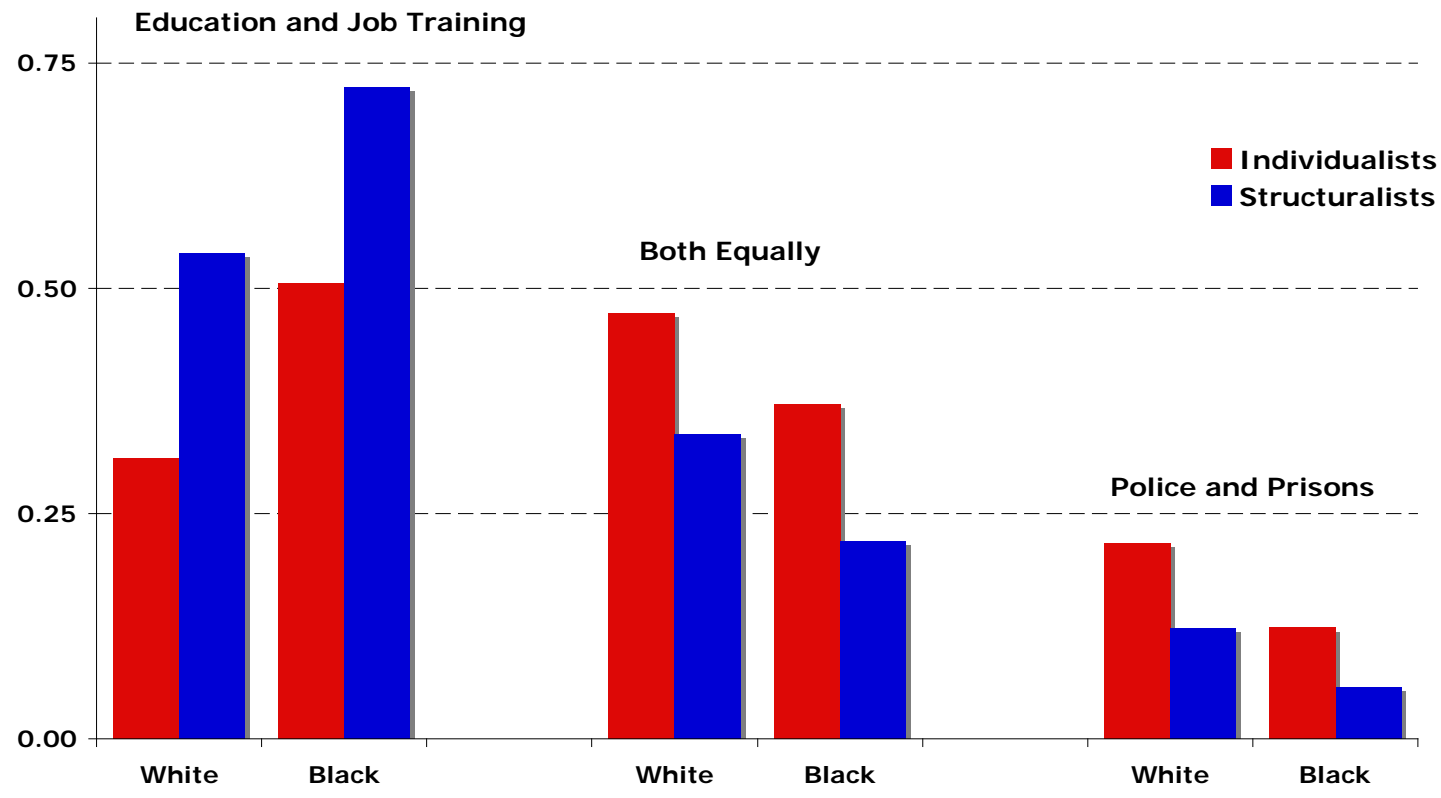

Source: Race, Crime and Public Opinion Survey, 2001

Figure 2b. Predicted Probability of Support for Making Parole Boards "More Strict" versus "Less Strict/ leaving them the same" for I ndividualists and Structuralists by Race

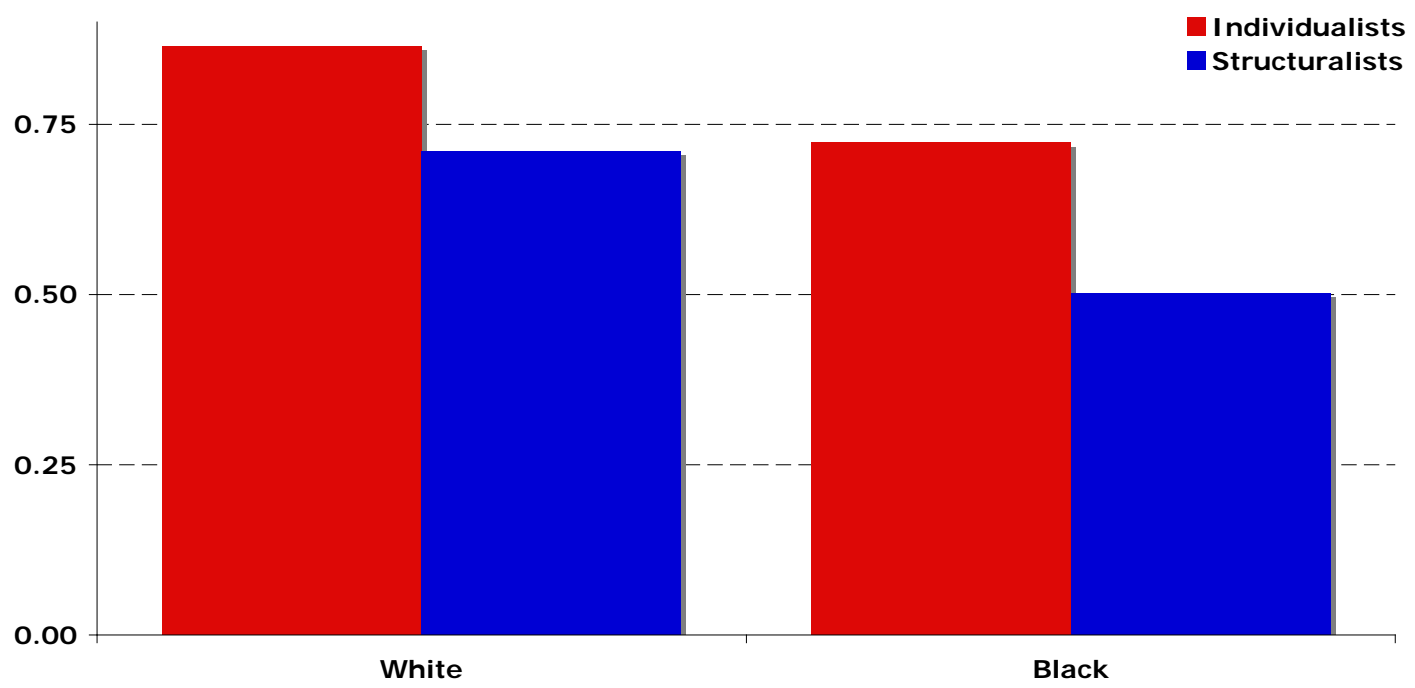

Source: Race, Crime and Public Opinion Survey, 2001 